\title{
Mother Tongue Use in Beginner EFL Grammar Classes in Saudi Arabia: A Case Study
}

\author{
Khulud Ali Tubayqi
}

Female Art and Humanity College, Jazan University, Saudi Arabia

\section{Mazeegha Ahmed Al Tale'}

Faculty of Languages and Translation, King Khalid University, Saudi Arabia

Corresponding author: maltale@kku.edu.sa

Received: 8/23/2021

Accepted: 11/22/2021

Published: $12 / 15 / 2021$

\begin{abstract}
Using the mother tongue (MT) in English as a foreign or second language (EFL/ESL) classrooms is indispensable, especially in beginner classes. This paper aims to add to the present literature on this issue by highlighting the attitudes of both students and teachers towards MT use in English as a foreign language (EFL) classroom, the justifications for its use, and some of the actual interaction practices in grammar classes. It investigates the attitudes of 110 Saudi EFL female beginners and their two teachers toward using the Arabic language in EFL grammar classes at Jazan University. It also investigates the students' reasons for using or avoiding their MT. Moreover, it presents some of the functions that MT serves in EFL grammar classes. To collect the data, the researchers used two questionnaires and classroom observations. For data analysis, they used Microsoft Excel and thematic content analysis. The results indicated that, although both students and teachers generally have positive attitudes toward using the MT in EFL classes, they are also aware of the adverse effects of its overuse. The results also revealed that the teachers and students use MT in EFL classes to serve different classroom functions that ease the teaching and learning processes. Based on these findings, the study provided recommendations for teachers, curriculum designers, and future researchers.

Keywords: Arabic, attitudes, English as a foreign language (EFL), functions, grammar, mother tongue (MT), reasons, Saudi Arabia context

Cite as: Tubayqi, K. A., \& Al Tale', M. A. (2021). Mother Tongue Use in Beginner EFL

Grammar Classes in Saudi Arabia: A Case Study. Arab World English Journal, 12 (4) 349 -365.

DOI: https://dx.doi.org/10.24093/awej/vol12no4.23
\end{abstract}




\section{Introduction}

Throughout the evolution of teaching methods for English as a foreign or second language (EFL/ESL), applied linguists have given considerable attention to the use or lack of use of the mother tongue (MT) as a basic principle (Larsen-Freeman, 2000). The earliest method (the Grammar-Translation Method) recommended using the MT as a fundamental principle to teach grammar rules. After that, the Direct Method introduced a shift concerning MT use, which banned using MT to teach English in EFL/ESL classes. Later, after a series of different teaching methods with various positions regarding the MT status in the classroom, the Communicative Teaching Method called for MT use only when necessary. As Uyar (2012) indicated, the effectiveness of using MT in English as a foreign language (EFL) classroom depends upon the teaching context and upon factors other than the strategy itself. Therefore, research in different contexts of EFL teaching has revealed varying results (Turnbull \& Evans, 2017; Al-Enezi, 2018; Al-Zayed, 2019; Binmahboob, 2020).

Teaching grammar is a fundamental aspect of teaching languages. It helps learners better understand and learn a language. However, learning the grammars of foreign languages is sometimes challenging for new EFL learners, especially if they are different from their native tongue's grammar. Levine (2014) indicated that grammar is associated with the learners' identities, just as it connects to other language entities. Harmer (1991) indicates that EFL speakers are inclined to compare the grammars of their MT with those of English. Paradowski (2007) states that if the purpose of MT use is to aid second language(L2) learners to understand a grammatical rule, such use is probably the most economical one. He adds that "careful, judicious, and timely use and position of the L1 in the classroom which helps the students get the maximum possible benefit from the lesson should thus be countenanced." (p. 153).

When Saudi secondary school students go to college, they are not usually proficient in understanding English. Al-Nofaie (2010) states that the weekly number of English sessions for school students (four) and the allocated time for each session (45 minutes) do not give them sufficient exposure to the language. Saudi students also do not usually use English extensively outside school and college. Thus, college courses are taught at a higher level of English than students' actual proficiency level after finishing general education programs due to the reasons mentioned above: lack of sufficient target language (TL) input in school and encountering incomprehensible input beginners in college. Krashen (1982) highlights this problem of lack of comprehensible input in his comprehensible input hypothesis. He states that learners should receive comprehensible input to internalize it and learn the TL. He also provides a condition for this input to be comprehensible: it should be only one level above the learners' current level.

Teachers of beginner classes in college usually reduce incomprehensible input by switching to the students' MT while explaining English grammar concepts (Masrahi, 2016; Adil, 2019). Masrahi (2016) states that teachers and students commonly use MT in Saudi EFL college classrooms and that this is a strategy employed by bilingual teachers to facilitate the educational process. In addition, conversing in the MT can also help teachers explain delicate lexical items, effortlessly clarify meanings, and provide more linguistic input to young students simultaneously learning two languages (Canale, 1983; Brown, 2001; Murad, 2013). Thus, MT is considered a facilitating tool in the English classroom for beginners (Al-Nofaie, 2010; Al-Katheery, 2014; Adil, 2019). 
However, Adil (2019) concludes that although the MT use is beneficial in explaining new English vocabulary meanings, it has some adverse effects, and the teachers should ensure the dominance of the TL in the classroom. Therefore, the related literature addressing this issue varies regarding its findings regarding MT use in EFL classes.

\section{Literature Review \\ Positive Effects of MT Use in EFL Classes}

Much of the previous literature has supported MT use in EFL classes due to its essential functions. For example, Greggio and Gil (2007) stated that shifting to the MT in EFL classrooms may facilitate communication and learning. Brooks-Lewis (2009) indicated that the Spanishspeaking learners in Mexican colleges viewed the inclusion of their L1 in the classroom as helpful to their EFL learning experience. Using classroom recordings and questionnaires in her study, Jingxia (2010) concluded that code-switching is widespread in some Chinese EFL college classrooms and has a positive role in EFL teaching and learning. Demir (2012) emphasized that L1 facilitates Turkish students' self-confidence in learning grammar, and Debreli and Oyman (2015) concluded that Turkish students expressed positive perceptions toward using L1 in their L2 classes and for the lower-level students.

Moreover, Turnbull and Evans (2017) concluded that the L1 discussion positively affected the reading comprehension of Japanese EFL university students and called for implementing judicious use of the MT in classrooms. In the same year, Shabir (2017) showed that limited L1 use in teaching Applied Linguistics for master's program students at the University of Queensland, Australia is necessary and beneficial for certain activities. Moreover, Kocaman and Aslan (2018) concluded that Turkish students seemed willing to use their MT while learning English.

Besides, Narayan (2019) called for the judicious use of MT in Fijian English as a second language (ESL) classrooms because it increases interaction. More recently, Aoyama (2020) called for the EFL Japanese high school teachers' MT use in their classrooms in conjunction with communicative teaching strategies.

In the Saudi context, Jenkins (2010) suggested that using only the TL in Saudi EFL classrooms might not suit the context and called for re-examining the current educational policy. Al-Nofaie (2010) stated that the students' main uses of MT in a Saudi intermediate school for females are for "giving exam instructions, translating words, contrasting the two languages, explaining grammar, asking questions, and participating in pair work" (p. 78). Al-Shammari (2011) also concluded that MT was applied in English classes at technical colleges in Saudi Arabia to ease the language learning process and increase students' comprehension.

In addition, Khresheh (2012) showed that Saudi EFL teachers used translations to explain English and that students used Arabic to express themselves, with MT serving as a means of encouragement and securing a comfortable learning environment. Finally, Al-Enezi (2018) pointed out that MT use in Saudi EFL classes helps clarify course content, stating that students are more attentive and less confused when teachers instruct them in their MT. 


\section{Adverse Effects of MT Use in EFL Classes}

Some of the previous literature has supported the sole use of TL in the EFL/ESL classrooms and reported adverse effects of MT use. For example, Nazary (2008) showed that Iranian university students rejected L1 use in EFL classes to a great extent, indicating that intermediate students had stronger negative attitudes toward the MT than beginner and advanced-level students. Using classroom observations and two focus group interviews with secondary-level students and their teachers, Khati's (2011) study offered simple and practical strategies for enhancing TL use in Nepali EFL secondary school classrooms. In addition, Romli and Abd Aziz (2015) showed that although both inexperienced and experienced English teachers in Pahang University, Malaysia, used Malay to teach English, the inexperienced teachers had positive views on its use and the experienced ones had negative ones.

More recently, Al-Zayed (2019) stated that although the Jordanian teachers used MT to teach English and explain new vocabulary effortlessly, they believed it reduced teaching quality. Also, Wijaya, Mety, and Bram (2020) concluded that the students and their teachers in Master program students specialized in English education in Indonesia used MT. However, they recommended that MT is better used in informal social interactions than EFL/ESL educational contexts since it will hinder students from gaining TL interaction skills.

Also, in the Saudi context, Mahmoud (2012) concluded that MT use negatively affected the foundational year for Saudi EFL students at King Abdul-Aziz University and recommended avoiding that use. Instead, he suggested using creative inductive teaching techniques in grammar, such as simplifying, miming, drawing, and acting. Four years later, Masrahi (2016) commented that the low-level EFL learners taught by teachers from multilingual backgrounds use the MT to accomplish learning and social behaviors. He indicated that using L1 minimizes the students' positive contribution and does not provide them the full opportunity to speak in the TL in the classroom. He also recommended that the English Language Centre at Jazan University develop a strategy to minimize MT use to teach English to the lowest possible level.

Two years later, Al-Mohaimeed and Al-Murshed (2018) concluded that while Saudi EFL female elementary college students hold positive views about MT use in English classes during their preparatory year, the advanced intermediate students hold negative attitudes toward it. More recently, Binmahboob (2020) indicated that although Saudi EFL secondary school class teachers in Riyadh admit that MT has many pedagogical functions, they encourage students not to depend upon it in the classrooms. The teachers also believe that the MT role is inadequate within the communicative approach, positing that it hinders language teaching, and its use must be restricted.

\section{Rationale and Research Questions}

As seen in the literature above, several studies in the Saudi context have investigated this issue in different schools and universities (Al-Nofaie, 2010; Mahmoud, 2012; Masrahi, 2016; Binmahboob, 2020). These studies have arrived at different conclusions on MT use in EFL Saudi classes. However, none of the studies investigated the attitudes of both EFL Saudi college teachers and their beginners toward using the MT, the justifications for its use, and the actual interaction practices in grammar classes. Thus, it is crucial to investigate this issue to contribute to the current literature. Furthermore, since attitudes, reasons, and practices are crucial aspects of 
teaching a foreign language, it is beneficial to investigate them to broaden the current literature on this issue for EFL teachers, curriculum designers, administrators, and future researchers.

Therefore, the present study focuses on two female beginner grammar classes at Jazan University, Saudi Arabia. It investigates students' attitudes toward using Arabic in EFL grammar classes and their justifications for using or avoiding it. It also investigates the teachers' perceptions of such use and why they use the MT in their classes. Further, it sheds light on the actual teaching and learning practices related to this issue. Specifically, the study aimed to answer the following questions concerning Jazan University:

1. What are the Saudi female EFL beginners' attitudes toward using the Arabic language in EFL grammar classes?

2. What are the reasons for beginners using or avoiding the Arabic language in EFL grammar classes?

3. What are the teachers' attitudes towards using the Arabic language in EFL grammar classes and its purposes?

\section{Methodology}

\section{Context and Participants}

The researchers conducted the present study during the second semester of 2019-2020 in the English Department of Female Art and Humanity College at Jazan University. Two bilingual female grammar instructors and their students were selected. Both teachers are bilingual, in Arabic and English. The teachers have five and ten years of grammar teaching experience for preparatory-year beginners. The first instructor taught two grammar classes consisting of 45 students in each class, while the second instructor taught two grammar classes with 13 students in the first class and 7 in the second. The whole number of student participants who completed the questionnaire was 85 . However, all the 110 students were observed studying levels 1 and 2 of all the English language skills and Grammar 1 and 2. The prescribed textbook for Grammar 1 and 2 was English Grammar in Use by Raymond Murphy (2012). The students' performance ranged from a Grade Point Average (GPA) of 2.27 to 3.98, with an average of 3.78. Thus, the participants were a representative sample of beginner-level students and teachers from the English Department. Therefore, those participants were considered suitable for exploring the attitudes of Saudi female college beginners and their teachers toward using their MT in EFL classes and their classroom practices of that use.

\section{Research Instruments and Data Collection Procedures}

The researchers used two questionnaires and classroom observation checklists from AlNofaie (2010) to collect the data. These instruments are illustrated below:

\section{Student Questionnaire}

The student questionnaire was used, with minor modifications, to elicit the college students' attitudes toward MT use in English Grammar classes and the reasons behind such usage. The questionnaire consisted of a frequency scale of five points, ranging from "always" to "never," as Al-Nofaie (2010) established, to facilitate quantitative data collection and to attain reliability (see Appendix A). The questionnaire consisted of 15 close-ended and two open-ended questions. The answers to the close-ended questions were on a five-point scale, ranging from "always" to "never," and elicited the frequency of MT use those students found acceptable in EFL classes. 
The two open-ended questions included documenting why students are encouraged to use Arabic in the classroom or avoid such use. The researchers employed an Arabic version of the questionnaire to facilitate participant comprehension. The target participants received the questionnaire electronically. They were encouraged to ask the principal researcher about any clarifications during her presence to observe their classes. Eighty-five of the student participants returned the questionnaire completed within two weeks, as requested.

\section{Teachers' Questionnaire}

The instructors of the four classes were given an open-ended question questionnaire, which consisted of five questions taken from Nofaie's (2010) semi-structured interview (see appendix B). The two teachers had one day to read and answer the questions carefully. The procedure differed from Nofaie's (2010) interviews in that the two teachers refused to be audio-recorded and reported that they were busy with other lectures within the department during the working days. Thus, to elicit their responses satisfactorily, they were given the questions to write their answers at their convenience. The first question was whether they agree with language educators who believe that the MT should be excluded from EFL classes. The second one inquired whether they use the Arabic language in their classes, and if so, for what purposes. The third question was modified to ascertain whether they believe their students' language proficiency level would be affected by the Arabic used in the classroom. The fourth question asked whether they believed using Arabic is indicative of less creative teaching. The final question asked whether they allowed their students to use the Arabic language in class and why or why not. This qualitative questionnaire aimed to gain more information to investigate whether using the Arabic language in the EFL classroom is helpful for the investigated teachers.

\section{Observation Checklists}

The principal researcher attended four lessons during her visit to the English department at Jazan University and completed the observation documents. Two observation checklists taken from Al-Nofaie's (2010) were modified and used (see appendix C). They were modified to suit college-level context since Al-Nofaie's study was conducted on secondary school students. They identify three different stages for teachers and students: beginning, during, and after the lectures. Using these observation checklists, the principal researcher observed two lessons each in Grammar 1 and Grammar 2. Each lesson had a two-hour duration. In addition, the researcher closely observed the purposes for which the two teachers and their students used the Arabic language in their routine lessons.

\section{Data Collection and Analysis Procedures}

The data collection procedures continued for two weeks. Before applying the three methods of data collection, the researchers obtained an approval letter from Jazan University. As a necessary research procedure, the researcher informed both teachers and students of the aim of the study. The students were told not to write their names on the questionnaire to obtain accurate and valid results. Moreover, the researcher attended four lectures in four different classes (two classes for each EFL teacher). After the data collection process, the researchers used both qualitative and quantitative data analysis procedures. The qualitative portion of the student and teacher questionnaires and the classroom observation checklists were analyzed manually, based on thematic content analysis processes. The quantitative portion of the student questionnaires 
was analyzed statistically using Microsoft Excel to calculate the frequencies and percentages of the student responses.

\section{Results}

\section{Students' Attitudes Toward Using MT EFL Classes}

The student questionnaire results generally revealed positive attitudes toward using MT (Arabic) in EFL classes. The results displayed that more than half of the investigated students (63.5\%) prefer teachers to use Arabic in English classes, and 70.5\% prefer teachers to use Arabic if the lesson is boring. Also, $89.3 \%$ of the students believe that teachers should clarify challenging activities in Arabic. As for the MT value in explaining grammar rules and new vocabulary, $74 \%$ of the students believe grammar should be explained in Arabic; $87 \%$ believe that new vocabulary should be explained in Arabic; $70.5 \%$ of them reported they understand the new vocabulary when using bilingual dictionaries.

In addition, $83.4 \%$ prefer that their teachers present grammar lesson instructions in the Arabic language. In addition, $83.4 \%$ believe they can better understand the lesson when the teacher uses Arabic. Moreover, $85.8 \%$ of the students believe the teacher should explain the differences and similarities between Arabic and English in Arabic. Finally, 83.4\% reported that they feel more comfortable when exam instructions are given in Arabic. Concerning the students' MT use in EFL classes, most of them (72.8\%) prefer to ask their teacher questions in Arabic, and $62.3 \%$ of them prefer doing an activity with a partner in Arabic. Furthermore, $72.8 \%$ of the investigated students felt comfortable communicating with the teacher in Arabic; $83.4 \%$ reported that they feel more comfortable when exam instructions are given in Arabic; $87 \%$ feel that Arabic helps them express their feelings and ideas better than English. However, $44.6 \%$ of the investigated students think that using Arabic prevents them from learning English.

\section{Reasons for MT Use in English Classes}

Concerning the reasons that encourage the students to use MT in English classes, they reported that it is because they are in the preparatory year, and their English-speaking level is low as they lack adequate grammar and vocabulary to speak in English. The students also reported they use MT to understand the meanings of the new words accurately; that it helps them understand the grammatical rules better, learn how to answer questions, and obtain more precise clarifications from their teachers. Finally, they stated that MT helps them interact and communicate with teachers more quickly and easily.

\section{Reasons for Avoiding MT Use in English Classes}

The student participants reported they avoid using MT in English classes for various reasons. Sometimes, teachers mandate English only. At other times, the students themselves do not wish to switch to Arabic while speaking English. They know that speaking in MT sometimes forms a barrier to learning a new language. They believe they should speak English and overcome the fear of failure and shyness. In addition, they want to practice speaking the English language with their classmates, which will help them learn new vocabulary. Students also stated that they would avoid their MT if they were able to use the TL easily. They described future cases during which they would avoid using MT in English classes. They reported that they would use only TL if they were fluent in it and if it were easy for them to speak and completely understand words and meanings and understand the grammar thoroughly. 


\section{Teachers' Attitudes Toward MT Use in EFL Classes}

\section{MT Exclusion from EFL Classes}

Both teachers rejected the idea of excluding MT from English classes. Instead, they mentioned that using MT (Arabic) helps students better understand grammar and that using only the English language blocks students' comprehension. The analysis of the observation sheets showed that the two teachers used their MT in teaching grammar. Some of their uses are illustrated in the section below:

\section{MT Use Purposes in EFL Classes}

Regarding the purposes of MT use in grammar classes, both teachers reported that they usually use it when necessary and as a last resort. They also reported that they use it to help their students understand English grammar better, check their comprehension, translate the new vocabulary and sentences to them, and help them learn better since they will learn better if they understand the meanings in their MT. Both teachers agreed that using Arabic in the classroom is helpful because of the students' lack of competence in the grammatical rules and new words and structures. The classroom observations verified the teachers' attitudes towards the purposes for which they use MT. Based on the classroom observations, both teachers use Arabic and encourage students to work with peers using Arabic to complete class activities more effectively. They use it to introduce, ask questions, reply to their students' requests, give instructions, check for students' understanding, and translate vocabulary (See Appendix C).

\section{MT Negative Impact on Students' English Proficiency Level}

As for the negative effect of the MT use on students' English proficiency level, both instructors agreed that the students' English skill levels would be affected by the Arabic used in the classroom, especially when studying at an advanced level. In addition, teachers agreed that using too much Arabic would affect students' academic skills in the future. For example, one of the teachers reported that the students would struggle to remember the English words if she used Arabic and translation. She also indicated that excessive use of Arabic in English classes would affect their English spelling negatively.

\section{MT Use Impact on Teaching Creativity}

Both teachers agreed on the potential negative impact of MT use on teaching creativity. They reported that there is often not enough time to complete lessons; thus, using Arabic expedites the teaching process. Therefore, the lack of suitable teaching settings, tools, and time will increase MT use in EFL classes as a strategy that makes teaching and learning faster. One of them stated that Arabic use affects teaching creativity, but she added: "using a little Arabic will not harm."

\section{Allowing Students to Use MT}

Finally, regarding whether instructors allow students to use Arabic, they reported that their students use it when asked. Furthermore, they want to ensure that their students better understand grammar, and when they cannot express themselves in English, they may do so in Arabic. Classroom observation showed that most students use Arabic in English grammar classes, preferring to employ the language when facing difficulties in learning grammar. Additionally, it was observed that the students felt comfortable and had a great desire to acquire English grammar through Arabic, which saved the teachers time and protected the students from 
feelings of frustration while learning English. They used MT in grammar classes to make requests, such as (Mumkin niqafil Al-mukayf? ممكن تيتشر نقفل المكيف؟ "Is it possible to switch off the AC?”), ask their classmates questions, such as (Kam raqam tamrīnik? "What is the number of your exercise?"), ask their teachers questions such as, (Hal naktub kul Al-qwā 'id هل هل نكتب كل الثلاث القو اعد اللمبني للمجهول في فقرة واحدة؟) Al-thalath lilmabnī lilmajhwl fī faqarah wahidah "Shall we write all the three rules of passive voice in one paragraph?"), and answer questions, as in (Tamrīn̄ raqam thalāthah) تمريني رقم ثلاثة "My exercise is number three." and (N 'ām fâhimīn) "Yes, we understand."

\section{Discussion}

The findings showed that most female Saudi Arabian EFL students who participated in this study had positive attitudes toward using the MT (Arabic) in English grammar classes. This finding agrees with previous research on EFL students' attitudes toward MT use in EFL classes, indicating that EFL learners hold positive attitudes toward MT use in class (Brooks-Lewis, 2009; Al-Nofaie, 2010; Al-Shammari, 2011; Al-Mohaimeed and Al-Murshed, 2018; Kocaman and Aslan, 2018). However, this finding differs from Nazary's (2008) findings, reporting negative attitudes of the EFL students toward such use.

The findings also showed that the investigated students most commonly use Arabic because of their low English proficiency, limited English vocabulary, and inadequate grammar knowledge that lessens their ability to speak English. Therefore, MT use enables them to receive more precise clarifications from their teachers and communicate more effectively. These reasons for MT use align with Brown's (2001) claim that MT use is beneficial in clarifying the meaning of complicated items in the TL through translation. They are also congruent with previous research findings that support L1 as a tool for clarifying and explaining the TL (Brooks-Lewis, 2009; Khresheh, 2012; Al-Enezi, 2018). Furthermore, these reasons support previous research reporting MT use for interaction and communication in the classroom (Narayan, 2019; Aoyama, 2020).

In addition, the findings indicated the students' awareness of the importance of avoiding excessive MT use in EFL classes. They reported that it forms a barrier to learning the TL and prevents them from practicing English speaking with their classmates. They stated they would have avoided MT use if they were fluent in English and had sufficient vocabulary and command of English grammar. Furthermore, they claimed that their positive attitudes towards using their MT would change when they reach higher levels. This claim indicates their awareness that such use is a temporary tool to be utilized only in beginner classes and that it has shortcomings in advanced EFL classes. The students' views above support Al-Mohaimeed and Al-Murshed's (2018) conclusion that while preparatory-year female Saudi college students in beginner EFL classes hold positive attitudes toward MT use in English classes, advanced intermediate students hold negative attitudes toward such use. They also support Nazary's (2008) finding that the intermediate Iranian university students had stronger negative attitudes toward MT use than the beginner-level students.

Similarly, although the teachers have positive attitudes towards MT use in EFL classes, they are aware that the students should use it only when they fail to understand the rules in English and when the teacher has no time to explain them in English. Furthermore, they believe that MT use in EFL classes has adverse effects, especially if the students are studying at an 
advanced level, and that it will negatively affect the creativity of teaching, students' academic English skills, and their ability to think critically in English. These findings are similar AlZayed's (2019) indication that although teachers use MT to teach English effortlessly and explain new vocabulary, they believe it reduces the teaching quality. They also support Binmahboob's (2020) conclusion that it should not be used without restrictions despite the MT pedagogical functions since its role is inadequate within the communicative approach.

Finally, the study findings revealed some of the teachers' uses of MT in EFL classes, such as introducing, asking questions, replying to students' requests, providing instructions, verifying understanding, and translating vocabulary. Likewise, the findings revealed some of the students' uses of MT, such as requesting, asking, and answering questions. These uses go with previous research on the MT functions in EFL classes (Brown, 2001; Greggio and Gil, 2007; Khresheh,2012; Masrahi, 2016; Al-Enezi, 2018). They also align with Binmahboob's (2020) conclusion that EFL teachers in Riyadh secondary schools admit that MT use has many pedagogical functions in EFL classes. However, they do not align with Mahmoud's conclusion (2012) that teachers should avoid using the MT in classes and use simplifying, miming, drawing, and acting to teach grammar inductively.

\section{Conclusion}

The findings above showed that although most of the investigated Saudi EFL preparatoryyear beginners at Jazan University appreciate MT's various essential functions in EFL beginner classrooms, they realize it is not a suitable strategy for them when they reach higher levels in the English language education. The results also showed that although both teachers use MT to perform some teaching functions, they believe that teachers should control such use and that it should be only when necessary and for EFL beginners.

\section{Implications, Recommendations, and Limitations}

The above findings have practical implications for grammar EFL/ESL learning and teaching. For example, EFL grammar teachers for beginners might allow their students to use their MT in EFL classes to express their feelings and ideas clearly, understand the instructions and activities, and be comfortable interacting with teachers and colleagues. The teachers can also use the MT to clarify new vocabulary and grammatical structures and communicate effectively with their students in the classroom. However, both teachers and students should realize that this strategy should be limited, used only when necessary and at beginner levels. Also, curriculum designers might include practical Arabic guidelines for EFL students and in prescribed books to understand English grammar rules better. Moreover, English department administrators should realize the importance of incorporating some MT use into EFL classes and understand the bilingual teachers' inclination to use it in English classes.

The current research has some limitations:

1. It focused on only four beginner EFL classes and their two teachers. Future research can be conducted on a larger sample for greater generalizability of findings.

2. Due to the restriction of the research context, the researchers did not record the interviews or classroom interactions. Further research can utilize recorded interviews with teachers and students and recorded lessons to obtain more accurate and documented findings. 
3. The present study was conducted in only one Saudi University. Further detailed classroom research in other Saudi universities could help support or reject the findings on MT inclusion in beginner EFL grammar classes in Saudi Arabia.

\section{About the Authors:}

Khulud Ali Tubayqi is a lecturer at Jazan University, English department. She holds a master's degree from King Khalid University, majoring in Applied Linguistics. She has rich experience in teaching English as a foreign language (EFL) to Saudi students. Her research interests are EFL teaching, language planning and discourse analysis. ORCid ID: https://orcid.org/0000-00032543-9928

Mazeegha Ahmed Al-Tale' is an associate professor of Applied Linguistics in the Faculty of Languages and Translation-King Khalid University, Saudi Arabia. She has taught several English Language courses for graduate and postgraduate students. She has also published articles in local, Arabic, and international journals. Her research interests are English as a foreign language (EFL)learning and teaching, e. Learning, and critical discourse analysis. ORCid ID: https://orcid.org/0000-0002-6355-8816

\section{References}

Adil, M. (2019). Practical Application of Learners' First Language to Teaching Meaning in EFL Classes: A Case Study Conducted in the Department of English at King Khalid University. Arab World English Journal, (1), 170-187. DOI: https://doi.org/10.24093/awej/efl1.13

Al-Enezi, M. (2018). Investigating Saudi Medical Students' Attitudes Towards English-Arabic Code-Switching in Classroom Instruction. The Asian ESP Journal, 14(1), 142-160.

Al-Katheery, E. (2014). Functions of Teacher Code-Switching in a Saudi EFL Classroom: A Case Study. TESOL Arabia Perspectives, 22(3), 18-24. Available at https://fac.ksu.edu.sa/ekathiri/publication/97071

Al-Mohaimeed, M. S., \& Al-Murshed, H. M. (2018). Foreign Language Learners' Attitudes and Perceptions of L1 Use in L2 Classroom. Arab World English Journal, 9(4), 433-446. DOI: https://dx.doi.org/10.24093/awej/vol9no4.32

Al-Nofaie, H. (2010). The Attitudes of Teachers and Students Towards Using Arabic in EFL Classrooms in Saudi Public Schools: A Case Study. Novitas-ROYAL (Research on Youth and Language), 4(1), 64-95.

Al-Shammari, M. M. (2011). The Use of the Mother Tongue in Saudi EFL Classrooms. Journal of International Education Research (JIER), 7(4), 95-102. DOI: https://doi.org/10.19030/jier.v7i4.6055

Al-Zayed, N., N. (2019). Using Arabic as the Mother Tongue in Teaching English as a Foreign Language. Dirasat, Human and Social Sciences, 46(4).

Aoyama, R. (2020). Exploring Japanese High School Students' L1 Use in Translanguaging in the Communicative EFL Classroom. The Electronic Journal for English as a Second Language, 23(4), 1-19. Available at https://files.eric.ed.gov/fulltext/EJ1242655.pdf

Binmahboob, T. (2020). Code-Switching and Attitudes Towards in EFL Classes from English Teachers' Perspective. Multi-Knowledge Electronic Comprehensive Journal for Education and Science Publications, 32, 1-38. 
Brooks-Lewis, K. A. (2009). Adult Learners' Perceptions of the Incorporation of their L1 in Foreign Language Teaching and Learning. Applied Linguistics, 30(2), 216-235. DOI: https://doi.org/10.1093/applin/amn051

Brown, H. D. (2001). Teaching by Principles: An Interactive Approach to Language Pedagogy ( $2^{\text {nd }}$ ed.). New-York: Longman.

Canale, M. (1983). From Communicative Competence to Communicative Language Pedagogy. In J. C. Richard, \& R. W. Schmidt (eds.), Language and Communication (pp. 2-27). Longman.

Debreli, E., \& Oyman, N. (2015). Students' Preferences on the Use of Mother Tongue in English as a Foreign Language Classrooms: Is it the Time to Re-examine English-Only policies? English Language Teaching, 9(1), 148. DOI: https://doi.org/10.5539/elt.v9n1p148

Demir, H. (2012). The Role of Native Language in the Teaching of the FL Grammar. Journal of Education, 1(2), 21-28.

Greggio, S., \& Gil, G. (2007). Teacher's and Learner's Use of Code-Switching in the EFL Classroom: A Qualitative Study. Linguagem and Ensino, 10(2), 371-393.

Harmer, J. (1991). The Practice of English Language Teaching ( ${ }^{\text {nd }}$ ed.). London: Longman. Jenkins, S. (2010). Monolingualism: An Uncongenial Policy for Saudi Arabia's Low-level Learners. ELT Journal, 64(4), 459-461. DOI: https://doi.org/10.1093/elt/ccq014

Jingxia, L. (2010). Teachers' Code-Switching to the L1 in EFL Classroom. The Open Applied Linguistics Journal, 2(1). DOI: https://doi.org/10.2174/1874913501003010010

Khati, A. (2011). When and Why of Mother Tongue Use in English Classrooms. Journal of NELTA, 16(1-2), 42-51. https://doi.org/10.3126/nelta.v16i1-2.6128

Khresheh, A. (2012). Exploring When and Why to Use Arabic in the Saudi Arabian EFL Classroom: Viewing L1 Use as Eclectic Technique. English Language Teaching, 5(6). DOI: https://doi.org/10.5539/elt.v5n6p78

Krashen, S. D. (1982). Child-Adult Differences in Second Language Acquisition: Series on Issues in Second Language Research ( $1^{\text {st }}$ ed.). Rowley, MA: Newbury House.

Kocaman, O, \& Aslan, E. (2018). The Students' Perceptions of the Use of L1 in EFL Classes: A Private Anatolian High School Sample. Journal of Language and Linguistic Studies, 14(4), 179-189.

Larsen-Freeman, D. (2000). Techniques and Principles in Language Teaching ( $2^{\text {nd }}$ ed.). Oxford: Oxford University Press.

Levine, G. S. (2014). Principles for Code Choice in the Foreign Language Classroom: A Focus on Grammaring. Language Teaching, 47(3), 332-348. DOI: https://doi.org/10.1017/S0261444811000498

Mahmoud, S. S. (2012). The Effect of L1 (Arabic language) in the L2 (English language) Classroom on the Achievement in General English of Foundation Year Students in King Abdulaziz University. David Publishing, 9(12), 1733-1738.

Masrahi, N. (2016). Causes of Code-Switching by Low Level EFL Learners at Jazan University, Saudi Arabia: A Teachers' Perspective. Journal of Language, Linguistics and Literature, 2(4), 24-31.

Murad, T. (2013). Arab Practicum Guides Code-Switch to Hebrew: Attitudes, Factors and Reasons. Journal of Language Teaching and Research, 4(6), 1160-1166. DOI: https://doi.org/10.4304/jltr.4.6.1160-1166

Murphy, R. (2012). English Grammar in Use: A Self-Study Reference and Practice Book for Intermediate Students of English ( $3^{\text {rd }}$ ed.). New York: Cambridge University Press 
Narayan, R. (2019). Code-Switching as a Linguistic Resource in the Fijian ESL Elassrooms: Bane or Boon? Journal of Language Teaching and Research, 10(3), 427. DOI: https://doi.org/10.17507/jltr.1003.04

Nazary, M. (2008). The Role of L1 in L2 Acquisition: Attitudes of Iranian University Students. Novitas-Royal, 2(2), 138-153. Available at http://novitasroyal.org/nazary.pdf

Paradowski, M. B. (2007). Foreign-Language Grammar Instruction via the Mother Tongue. In B. Frank, J. Darquennes, \& R. Temmerman (eds.), Multilingualism and Applied Comparative Linguistics, 1: Comparative Considerations in Second and Foreign Language Instruction (pp.151-167). Cambridge Scholars Press.

Romli, N. H., \& Abd Aziz, M. S. (2015). The Use of Bahasa Melayu in the English Language Classroom by 'Non-Optionist' English Teachers. Procedia-Social and Behavioral Sciences, 172, 770-777. DOI: https://doi.org/10.1016/j.sbspro.2015.01.431

Shabir, M. (2017). Student-Teachers' Beliefs on the Use of L1 in EFL Classroom: A Global Perspective. English Language Teaching, 10(4), 45-52. DOI: https://doi.org/10.5539/elt.v10n4p45

Turnbull, B., \& Evans, M. S. (2017). The Effect of L1 and L2 Group Discussions on L2 Reading Comprehension. Reading in a Foreign Language, 29(1), 133-154.

Uyar, Y. (2012). Using L1 to Enhance the Grammar Learning and Having Only English Policy in EFL Classes. Available at https://eric.ed.gov/?id=ED538967

Wijaya, K. F., Mety, M., \& Bram, B. (2020). English education Master's program students' perceptions on the use of code-switching in EFL classroom context. Journal of English Teaching, 6(1), 1-11. DOI: https://doi.org/10.33541/jet.v6i1.1336

\section{Appendix A: Students' questionnaire}

Dear student,

This questionnaire aims to investigate your attitudes toward using Arabic in English classes. Your responses will be highly appreciated since they will help improve English language teaching and learning. There are no correct or wrong answers. Your answers will be used only for investigation purposes and will be highly confidential.

\section{Section A:}

Please choose ONE answer which best reflects your attitude to the given statement. You can add further comments about the statements in the boxes.

1. I prefer my teacher to use Arabic in English classes.
A) Always
B) Often
C) Sometimes
D) Rarely
E) Never

2. I feel comfortable when I talk to my teacher in Arabic.
A) Always
B) Often
C) Sometimes

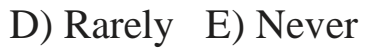

3. I can understand the lesson much better if my teacher uses Arabic.
A) Always
B) Often
C) Sometimes
D) Rarely
E) Never

4. I prefer the teacher to use Arabic if the lesson is boring.
A) Always
B) Often
C) Sometimes
D) Rarely E) Never

5. Arabic can help me to express my feelings and ideas that I cannot explain in English.
A) Always
B) Often
C) Sometimes
D) Rarely
E) Never

6. I prefer to ask my teacher questions in Arabic. 

A) Always
B) Often
C) Sometimes
D) Rarely
E) Never

7. I prefer to do an activity with a partner in Arabic.
A) Always
B) Often
C) Sometimes
D) Rarely
E) Never

8. I understand new vocabulary only when I use a bilingual dictionary.
A) Always
B) Often
C) Sometimes
D) Rarely
E) Never

9. The teacher should clarify difficult activities in Arabic.
A) Always
B) Often
C) Sometimes
D) Rarely
E) Never

10. English grammar should be explained in Arabic.
A) Always
B) Often
C) Sometimes
D) Rarely
E) Never

11. New vocabulary should be translated into Arabic.
A) Always
B) Often
C) Sometimes
D) Rarely
E) Never

12. Class instructions should be given in Arabic.
A) Always
B) Often
C) Sometimes
D) Rarely
E) Never

13. I feel comfortable if exam instructions are given in Arabic.
A) Always
B) Often
C) Sometimes
D) Rarely
E) Never

14. It is necessary to explain the differences and similarities between Arabia and English in Arabic.
A) Always
B) Often
C) Sometimes
D) Rarely
E) Never

15. Using Arabic prevents me from learning English.

Section B:
A) Always
B) Often
C) Sometimes
D) Rarely
E) Never

1. Please write down the reasons that encourage you to use Arabic in English classes.

2. Please write down the reasons that encourage you to avoid using Arabic in English classes.

Thank you for your cooperation!

\section{Appendix B: Teachers' questionnaire}

Name:

Years of teaching experience:

Dear teacher,

This qualitative questionnaire aims at investigating your perceptions of MT use in EFL classes. Your responses will help greatly improve English language teaching and learning. Your responses will be highly confidential and will be used only for research purposes.

1-Many language educators think that the mother tongue should be excluded from EFL classes. Do you agree?

2-Do you use Arabic in your classes? If so, for what purpose?

3- Do you think the amount of Arabic used in the classroom will affect your students' language proficiency level?

4- Do you think that using Arabic is a sign of less creative teaching?

5-Do you allow your students to use Arabic? Why / why not?

\section{We appreciate your time and cooperation!}


Arab World English Journal (AWEJ) Volume 12. Number 4. December 2021

\section{Appendix C: Observation checklist 1}

\begin{tabular}{llllll}
\hline At the beginning of lectures & Lesson 1 & Lesson 2 & Lesson 3 & Lesson 4 & Notes
\end{tabular}

Greeting

Chatting

Class instructions

Warm-up questions

During lectures

Translating words

Explaining grammar

Translating sentences

Clarifying activities

Referring to bilingual

dictionaries

Checking comprehension

Answering questions

At the end of lectures

Checking comprehension

Teacher's use of Arabic in grammar classes

Appendix D: Observation checklist 2

Students' uses of Arabic in grammar classes 
Arab World English Journal (AWEJ) Volume 12. Number 4. December 2021

Mother Tongue Use in Beginner EFL Grammar Classes in Saudi Arabia

Tubayqi \& Al Tale'

\begin{tabular}{llllll}
\hline At the beginning of & Lesson 1 & Lesson 2 & Lesson 3 & Lesson 4 & Notes
\end{tabular} lectures

Greeting

Chatting

During lectures

Asking

Questions

Working with peers

Using bilingual

dictionaries

Showing

understanding

Responding to

teacher's questions

At the end of lectures

Asking questions

Appendix C: Teachers' uses of MT in classrooms

\begin{tabular}{|c|c|c|}
\hline Functions & Examples & Translation \\
\hline Introducing & $\begin{array}{l}\text { U 'arifkum bī Al-istādhah Khulūd } \\
\text { اعرفكم بالاستاذة خلود }\end{array}$ & $\begin{array}{l}\text { I introduced you to the } \\
\text { teacher, Khulud }\end{array}$ \\
\hline Asking questions & 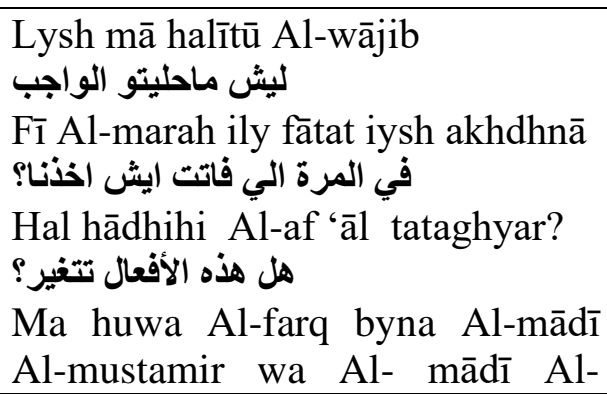 & $\begin{array}{l}\text { Why didn't you do the } \\
\text { homework? } \\
\text { For the last lesson, what did } \\
\text { we take? } \\
\text { Do these verbs change? } \\
\text { What is the difference } \\
\text { between past continuous } \\
\text { tense and simple past tense? }\end{array}$ \\
\hline
\end{tabular}




\begin{tabular}{|c|c|c|}
\hline & 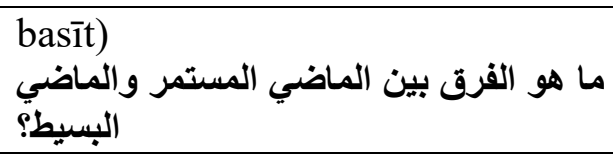 & \\
\hline Replying questions & $\begin{array}{l}\text { Student: Mumkin tītshar niqafil } \\
\text { Al-mukayf? } \\
\text { ممكن تيتشر نقفل المكيف؟ } \\
\text { Teacher: Idhā bardanīn tafū Al- } \\
\text { mukayf } \\
\text { إذا بردانين طفوا المكيف }\end{array}$ & $\begin{array}{l}\text { Student: Is it possible, } \\
\text { teacher, to turn off the AC? } \\
\text { Teacher: If you feel cold, turn } \\
\text { off the AC. }\end{array}$ \\
\hline Giving instructions & $\begin{array}{l}\text { Iftuhū Al-kitāb 'alá wihdit Al- } \\
\text { mādī Al-mustamir } \\
\text { افتحوا الكتاب على وحدة الماضي المستمر }\end{array}$ & $\begin{array}{l}\text { Open your book to the past } \\
\text { continuous unit. }\end{array}$ \\
\hline \multirow[t]{2}{*}{$\begin{array}{l}\text { Verifying } \\
\text { understanding }\end{array}$} & 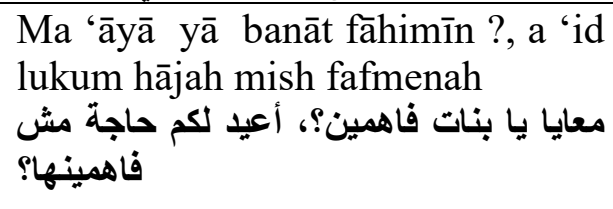 & $\begin{array}{l}\text { Do you understand me, girls? } \\
\text { Would you like me to repeat } \\
\text { anything you did not } \\
\text { understand? }\end{array}$ \\
\hline & 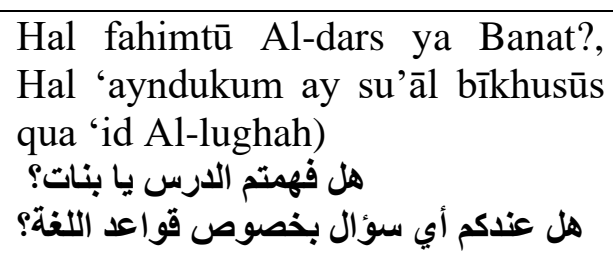 & $\begin{array}{l}\text { Did you understand the } \\
\text { lesson, girls? Do you have } \\
\text { any questions related to the } \\
\text { grammar rules? }\end{array}$ \\
\hline $\begin{array}{l}\text { Translating } \\
\text { vocabulary }\end{array}$ & 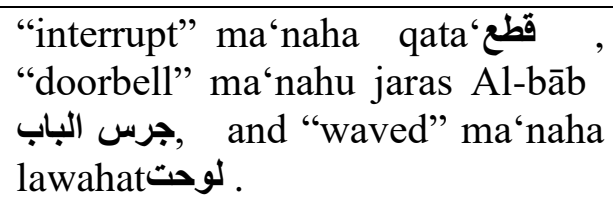 & $\begin{array}{l}\text { "interrupt" means qata" } \\
\text { "doorbell" means jaras Al- } \\
\text { bāb, and "waved" means } \\
\text { lawahat. }\end{array}$ \\
\hline
\end{tabular}

